\title{
ANALYSIS OF ELEVATED WATER STORAGE STRUCTURE USING DIFFERENT STAGGING SYSTEM
}

\author{
G.P.Deshmukh ${ }^{1}$, Ankush.S.Patekhede ${ }^{2}$ \\ ${ }^{1}$ Head of Civil Engineering Department, PLIT Engineering college Buldana, (M.S) 443001 \\ ${ }^{2}$ Lecturer Y.B.Patil polytechnic, Akurdi Pune
}

\begin{abstract}
From the very upsetting experiences of few earthquakes, like Bhuj earthquake (2001) in India R.C.C elevated water tanks were heavily damaged or collapsed. This was might be due to the lack of knowledge regarding the proper behaviour of supporting system of the tank due to the dynamic effect and also due to improper geometrical selection of staging. The main aim of this study is to understand the behaviour of different staging, under different loading conditions and strengthening the conventional type of staging, to give better performance during earthquake. Equivalent Static Analysis, for five different types of bracing systems, applied to the staging of elevated circular water tank in zone IV, is carried out using STAAD Pro. Comparison of base storey shear and nodal displacements of the container of circular water tank for empty, half filled and full condition is done.

Eleven models are used for calculating base shear and nodal displacements After calculating base shear and nodal displacements of eleven models for empty, half filled \& full condition of container applying with different types of bracing system in staging then economy point of view project study suggest such type of bracing which gives minimum base shear as well as considerable displacement for measure earthquake zones
\end{abstract}

Keywords: - water tank, stagging system, staad pro

$* * *$

\section{INTRODUCTION}

Water is human basic needs for daily life. Sufficient water distribution depends on design of a water tank in certain area. An elevated water tank is a large water storage container constructed for the purpose of holding water supply at certain height to pressurization the water distribution system. The liquid storage tanks are particularly subjected to the risk of damage due to earthquake-induced vibrations. A large number of overhead water tanks damaged during past earthquake. Majority of them were shaft staging while a few were on frame staging type Elevated water tanks consist of huge water mass at the top of a slender staging which are most critical consideration for the failure of the tank during earthquakes. Elevated water tanks are critical and strategic structures and damage of these structures during earthquakes may endanger drinking water supply, cause to fail in preventing large fires and substantial economical loss. Since, the elevated tanks are frequently used in seismic active regions also hence, seismic behavior of them has to be investigated in details. Due to the lack of knowledge of supporting system some of the water tank were collapsed or heavily damages. So there is need to focus on seismic safety of lifeline structure using with respect to alternate supporting system which are Safe during earthquake and also take more design forces. Hydrodynamic pressures on tanks under earthquake forces play an important role in the design of the tank. When the tank is in full condition, earthquake forces almost govern the design of these structures in zones of high seismic activity. The failure of these structures may cause some hazards for the health of the citizens due to the shortage of water or difficulty in putting out fire during the earthquake golden time. The performance of elevated water tanks during earthquakes is of much interest to engineers, not only because of the importance of these tanks in controlling fires, but also because the simple structure of an elevated tank is relatively easy to analyse and, hence, the study of tanks can be informative as to the behaviour of structures during earthquakes.

\subsection{Damage Observed to Elevated Water Tanks in}

\section{Bhuj Earthquake (2001)}

Most of the elevated water tanks undergo damage to their staging. Due to the lack of knowledge of supporting system some of the water tank were collapsed or heavily damages. So there is need to focus on seismic safety of lifeline structure using with respect to alternate supporting system which are safe during earthquake and also take more design forces.

Bhuj earthquake (2001) [2]is the recent example, as shown in figure $1.1,1.2, \& 1.3 \mathrm{It}$ is observed from the past earthquake; Most of the elevated water tanks undergo damage to their staging. 


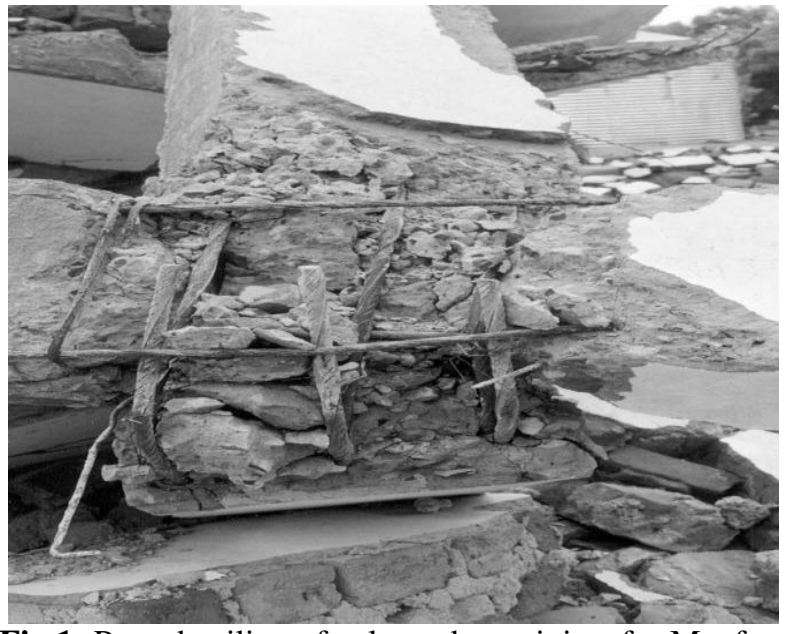

Fig 1: Poor detailing of column-brace joints for Manfera tank.

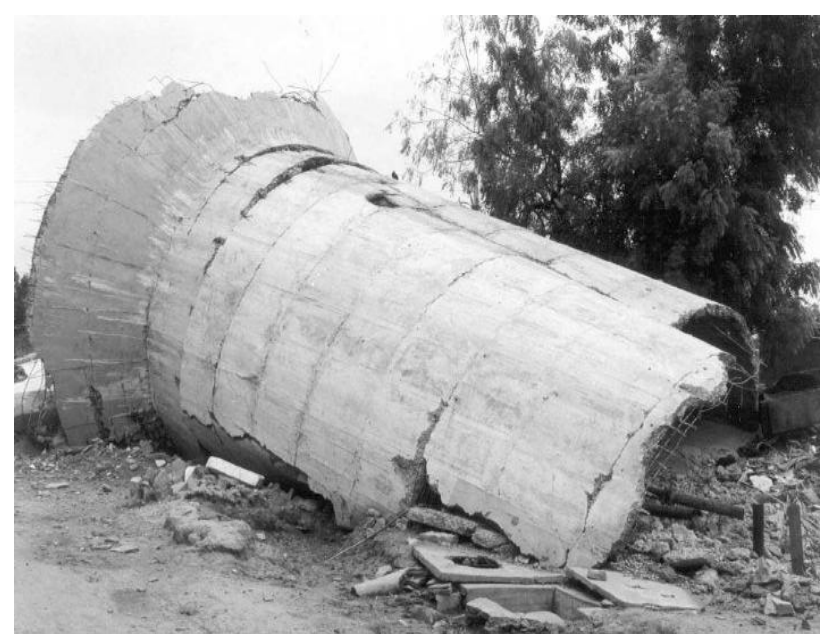

Fig 2: Collapse of water tank in Bhuj

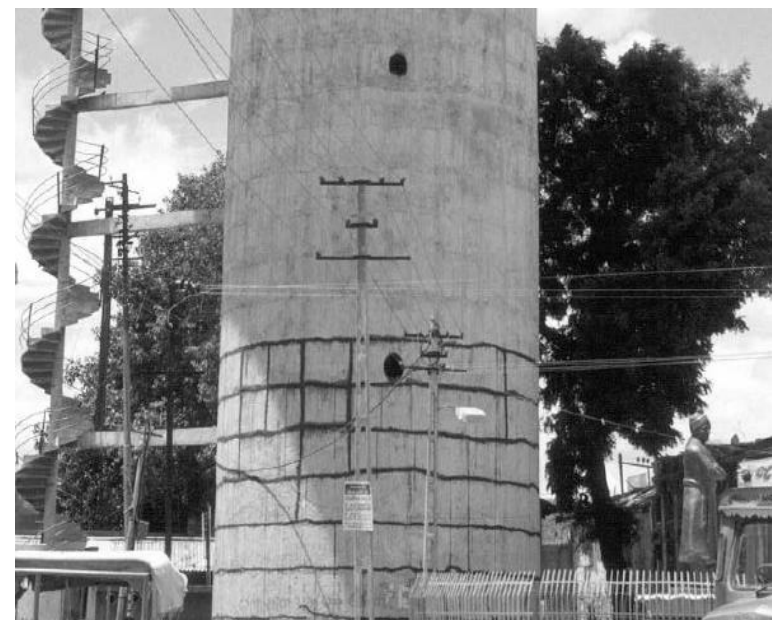

Fig 3: Flexure cracks in staging

\section{TYPES OF BRACING SYSTEM USED}

Models are used for calculating base shear and nodal displacements for staging with cross bracing, staging with chevron bracing, staging with diagonal bracing, staging with k-type bracing, staging with v-type bracing and alternate cross bracing in staging, alternate chevron bracing in staging, alternate k-type bracing in staging , alternate v-type bracing in staging., alternate diagonal bracing in staging.

\section{METHOD USED CALCULATING BASE}

\section{SHEAR}

STAAD.Pro.v8i is the most popular structural engineering software product for 3D model generation, analysis and multi-material design. It has an intuitive, user-friendly GUI, visualization tools, powerful analysis and design facilities and seamless integration to several other modeling and design software products. For static or dynamic analysis of bridges, containment structures, embedded structures (tunnels and culverts), pipe racks, steel, concrete, aluminum or timber buildings, transmission towers, stadiums or any other simple or complex structure, STAAD.Pro has been the choice of design professionals around the world for their specific analysis needs

\section{PARAMETERS OF ELEVATED WATER}

\section{TANK}

\begin{tabular}{|l|l|l|}
\hline S.N & Parameters & Values \\
\hline $\mathbf{1})$ & $\mathbf{( 2 )}$ & $\mathbf{( 3 )}$ \\
\hline 1 & size of top slab & $100 \mathrm{~mm}$ thick \\
\hline 2 & size of bottom slab & $150 \mathrm{~mm}$ \\
\hline 3 & size of top ring beam & $250 \times 350 \mathrm{~mm}$ \\
\hline 4 & size of bottom ring beam & $250 \times 500 \mathrm{~mm}$ \\
\hline 5 & size of column & $500 \times 250 \mathrm{~mm}$ \\
\hline 6 & size of braces & $500 \times 250 \mathrm{~mm}$ \\
\hline 7 & density of concrete & $25 \mathrm{kN} / \mathrm{sq} \cdot \mathrm{m}$ \\
\hline 8 & Diameter of tank & $10 \mathrm{~m}$ \\
\hline 9 & Height of tank & $5 \mathrm{~m}$ \\
\hline 10 & Height of staging & $15 \mathrm{~m}$ \\
\hline 11 & Number of columns & 10 \\
\hline 12 & Zone & IV(0.24) \\
\hline 13 & Response reduction factor & $5(\mathrm{SMRF})$ \\
\hline 14 & Importance factor & $\begin{array}{l}1.5 \\
\text { tank }\end{array}$ \\
\hline 15 & Type of soil & hard soil \\
\hline
\end{tabular}

\section{3D MODELS (FEW SYSTEM)}

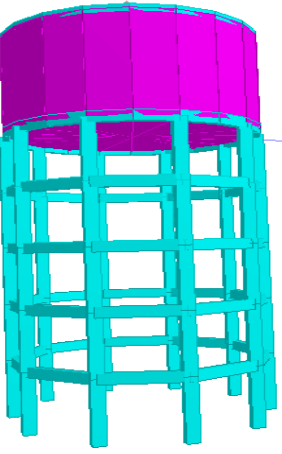

Staging without inclined bracing

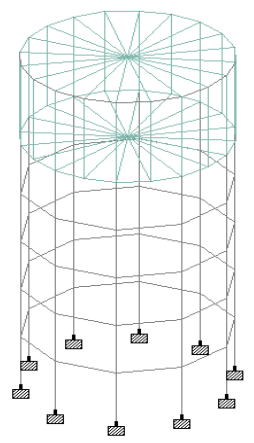

STAAD pro model of staging without inclined bracing 


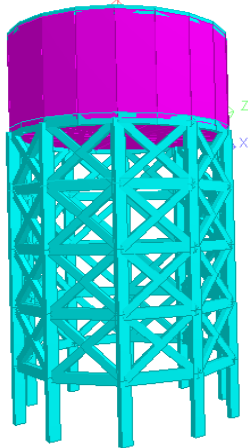

Staging with crossbracing staging

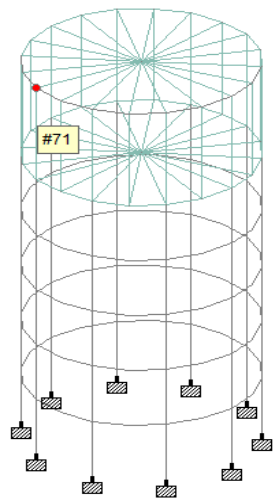

Position of node no.71

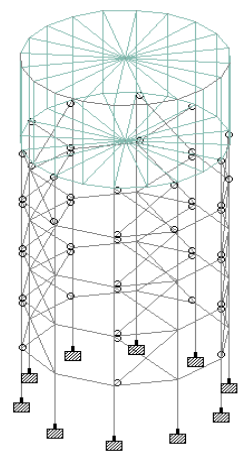

STAAD pro model of with cross bracing

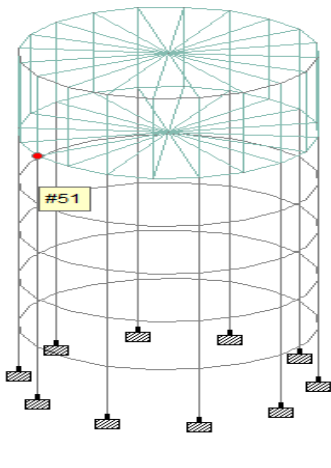

Position of node no.51

\section{RESULTS}

6.1 Results of Base Shear and Nodal Displacement of without inclined Bracing in Staging

\begin{tabular}{|l|l|l|l|l|}
\hline \multirow{2}{*}{ SN } & Tank condition & \multicolumn{2}{|l|}{ Displcement $\mathbf{( m m )}$} & $\begin{array}{l}\text { Base } \\
\text { shear } \\
(\mathbf{k N})\end{array}$ \\
\cline { 2 - 5 } & \multirow{2}{*}{$(\mathbf{1})$} & $\mathbf{( 2 )}$ & $\mathbf{( 3 )}$ \\
\cline { 3 - 5 } & & $\begin{array}{l}\text { Node } \\
\text { no:71 }\end{array}$ & $\begin{array}{l}\text { Node } \\
\text { no:51 }\end{array}$ & \\
\hline 1 & Empty & 12.5 & 12.1 & 99.910 \\
\hline 2 & Half & 15.0 & 14.6 & 119.94 \\
\hline 3 & Full & 17.5 & 17.1 & 139.89 \\
\hline
\end{tabular}

6.2 Results of Base Shear and Nodal Displacement of Cross Bracing in Staging

\begin{tabular}{|l|l|l|l|l|}
\hline \multirow{2}{*}{ SN } & Tank condition & \multicolumn{2}{|l|}{ Displcement $(\mathbf{m m})$} & $\begin{array}{l}\text { Base } \\
\text { shear } \\
\mathbf{( k N )}\end{array}$ \\
\cline { 3 - 5 } & \multirow{2}{*}{$(\mathbf{1})$} & $\mathbf{( 2 )}$ & $\mathbf{( 3 )}$ \\
\cline { 3 - 5 } & & $\begin{array}{l}\text { Node } \\
\text { no:71 }\end{array}$ & $\begin{array}{l}\text { Node } \\
\text { no:51 }\end{array}$ & \\
\hline 1 & Empty & 2.63 & 2.21 & 141.92 \\
\hline 2 & Half & 2.97 & 2.51 & 161.87 \\
\hline 3 & Full & 3.31 & 2.81 & 181.82 \\
\hline
\end{tabular}

6.3 Results of Base Shear and Nodal Displacement of Chevron Bracing in Staging

\begin{tabular}{|l|l|l|l|l|}
\hline \multirow{2}{*}{ SN } & Tank condition & \multicolumn{2}{|l|}{ Displcement $(\mathbf{m m})$} & $\begin{array}{l}\text { Base } \\
\text { shear } \\
(\mathbf{k N})\end{array}$ \\
\cline { 2 - 5 } & \multirow{2}{*}{$\mathbf{( 1 )}$} & $\mathbf{( 2 )}$ & $\mathbf{( 3 )}$ \\
\cline { 3 - 5 } & & $\begin{array}{l}\text { Node } \\
\text { no:71 }\end{array}$ & $\begin{array}{l}\text { Node } \\
\text { no:51 }\end{array}$ & \\
\hline 1 & Empty & 2.68 & 2.32 & 132.93 \\
\hline 2 & Half & 3.06 & 2.65 & 152.88 \\
\hline 3 & Full & 3.48 & 2.99 & 172.83 \\
\hline
\end{tabular}

6.4 Results of Base Shear and Nodal Displacement of Diagonal Bracing in Staging

\begin{tabular}{|l|l|l|l|l|}
\hline \multirow{2}{*}{ SN } & Tank condition & \multicolumn{2}{|l|}{ Displcement $(\mathbf{m m})$} & $\begin{array}{l}\text { Base } \\
\text { shear } \\
(\mathbf{k N})\end{array}$ \\
\cline { 2 - 5 } & \multirow{2}{*}{$(\mathbf{1})$} & $\mathbf{( 2 )}$ & $\mathbf{( 3 )}$ \\
\cline { 3 - 5 } & & $\begin{array}{l}\text { Node } \\
\text { no:71 }\end{array}$ & $\begin{array}{l}\text { Node } \\
\text { no:51 }\end{array}$ & \\
\hline 1 & Empty & 3.10 & 2.67 & 120.96 \\
\hline 2 & Half & 3.58 & 3.10 & 140.41 \\
\hline 3 & Full & 4.06 & 3.53 & 160.86 \\
\hline
\end{tabular}

6.5 Results of Base Shear and Nodal Displacement of k-Type Bracing in Staging

\begin{tabular}{|l|l|l|l|l|}
\hline \multirow{2}{*}{ SN } & \multirow{2}{*}{ Tank condition } & \multicolumn{2}{|l|}{ Displcement $\mathbf{( m m )}$} & $\begin{array}{l}\text { Base } \\
\text { shear } \\
\mathbf{( k N )}\end{array}$ \\
\cline { 2 - 5 } & \multirow{2}{*}{$(\mathbf{1})$} & $\mathbf{( 2 )}$ & $\mathbf{( 3 )}$ \\
\cline { 3 - 5 } & & $\begin{array}{l}\text { Node } \\
\text { no:71 }\end{array}$ & $\begin{array}{l}\text { Node } \\
\text { no:51 }\end{array}$ & \\
\hline 1 & Empty & 3.01 & 2.55 & 133.43 \\
\hline 2 & Half & 3.43 & 2.92 & 152.38 \\
\hline 3 & Full & 3.84 & 3.29 & 172.33 \\
\hline
\end{tabular}

6.6 Results of Base Shear and Nodal Displacement of v-Type Bracing in Staging

\begin{tabular}{|l|l|l|l|l|}
\hline \multirow{2}{*}{ SN } & Tank condition & \multicolumn{2}{|l|}{ Displcement $(\mathbf{m m})$} & $\begin{array}{l}\text { Base } \\
\text { shear } \\
\mathbf{( k N )}\end{array}$ \\
\cline { 2 - 5 } & \multirow{2}{*}{$\mathbf{( 1 )}$} & $\mathbf{( 2 )}$ & $\mathbf{( 3 )}$ \\
\cline { 3 - 5 } & & $\begin{array}{l}\text { Node } \\
\text { no:71 }\end{array}$ & $\begin{array}{l}\text { Node } \\
\text { no:51 }\end{array}$ & \\
\hline 1 & Empty & 3.02 & 2.57 & 132.93 \\
\hline 2 & Half & 3.44 & 2.94 & 152.88 \\
\hline 3 & Full & 3.86 & 3.32 & 172.83 \\
\hline
\end{tabular}




\subsection{Results of Base Shear and Nodal Displacement} of Alternate Cross Bracing in Staging

\begin{tabular}{|l|l|l|l|l|}
\hline \multirow{2}{*}{ SN } & Tank condition & \multicolumn{2}{|l|}{ Displcement $(\mathbf{m m})$} & $\begin{array}{l}\text { Base } \\
\text { shear } \\
\mathbf{( k N )}\end{array}$ \\
\cline { 3 - 5 } & \multirow{2}{*}{$(\mathbf{1})$} & $\mathbf{( 2 )}$ & $\mathbf{( 3 )}$ \\
\cline { 3 - 5 } & & $\begin{array}{l}\text { Node } \\
\text { no:71 }\end{array}$ & $\begin{array}{l}\text { Node } \\
\text { no:51 }\end{array}$ & \\
\hline 1 & Empty & 3.78 & 3.38 & 120.96 \\
\hline 2 & Half & 4.38 & 3.98 & 140.91 \\
\hline 3 & Full & 4.97 & 4.48 & 160.86 \\
\hline
\end{tabular}

6.8 Results of Base Shear and Nodal Displacement of Alternate Chevron Bracing in Staging

\begin{tabular}{|l|l|l|l|l|}
\hline \multirow{2}{*}{ SN } & \multirow{2}{*}{ Tank condition } & \multicolumn{2}{|l|}{ Displcement $(\mathbf{m m})$} & $\begin{array}{l}\text { Base } \\
\text { shear } \\
\mathbf{( k N )}\end{array}$ \\
\cline { 2 - 5 } & \multirow{2}{*}{$(\mathbf{1})$} & $\mathbf{( 2 )}$ & $\mathbf{( 3 )}$ \\
\cline { 3 - 5 } & $\begin{array}{l}\text { Node } \\
\text { no:71 }\end{array}$ & $\begin{array}{l}\text { Node } \\
\text { no:51 }\end{array}$ & \\
\hline 1 & Empty & 4.57 & 4.01 & 99.99 \\
\hline 2 & Half & 5.48 & 5.0 & 119.94 \\
\hline 3 & Full & 6.89 & 6.4 & 156.36 \\
\hline
\end{tabular}

\subsection{Results of Base Shear and Nodal Displacement} of Alternate Diagonal Bracing in Staging

\begin{tabular}{|l|l|l|l|l|}
\hline \multirow{2}{*}{ SN } & \multirow{2}{*}{ Tank condition } & \multicolumn{2}{|l|}{ Displcement (mm) } & $\begin{array}{l}\text { Base } \\
\text { shear } \\
(\mathbf{k N})\end{array}$ \\
\cline { 2 - 5 } & \multirow{2}{*}{$(\mathbf{1})$} & $\mathbf{( 2 )}$ & $\mathbf{( 3 )}$ \\
\cline { 3 - 5 } & $\begin{array}{l}\text { Node } \\
\text { no:71 }\end{array}$ & $\begin{array}{l}\text { Node } \\
\text { no:51 }\end{array}$ \\
\hline 1 & Empty & 5.52 & 4.83 & 108.37 \\
\hline 2 & Half & 6.22 & 5.75 & 128.33 \\
\hline 3 & Full & 7.18 & 8.66 & 148.28 \\
\hline
\end{tabular}

6.10 Results of Base Shear and Nodal Displacement of Alternate k-type Bracing in Staging

\begin{tabular}{|l|l|l|l|l|}
\hline \multirow{2}{*}{ SN } & Tank condition & \multicolumn{2}{|l|}{ Displcement $(\mathbf{m m})$} & $\begin{array}{l}\text { Base } \\
\text { shear } \\
(\mathbf{k N})\end{array}$ \\
\cline { 2 - 5 } & \multirow{2}{*}{$(\mathbf{1})$} & \multicolumn{2}{|l|}{$(\mathbf{2})$} & $\mathbf{( 3 )}$ \\
\cline { 3 - 5 } & & $\begin{array}{l}\text { Node } \\
\text { no:71 }\end{array}$ & $\begin{array}{l}\text { Node } \\
\text { no:51 }\end{array}$ & \\
\hline 1 & Empty & 4.18 & 3.75 & 116.71 \\
\hline 2 & Half & 4.86 & 4.39 & 136.66 \\
\hline 3 & Full & 5.55 & 5.03 & 156.61 \\
\hline
\end{tabular}

\subsection{Results of Base Shear and Nodal Displacement} of Alternate v-type Bracing in Staging

\begin{tabular}{|l|l|l|l|l|}
\hline \multirow{2}{*}{ SN } & Tank condition & \multicolumn{2}{|l|}{ Displcement $\mathbf{( m m )}$} & $\begin{array}{l}\text { Base } \\
\text { shear } \\
(\mathbf{k N})\end{array}$ \\
\cline { 2 - 5 } & \multirow{2}{*}{$\mathbf{( 1 )}$} & $\mathbf{( 2 )}$ & $\mathbf{( 3 )}$ \\
\cline { 3 - 5 } & & $\begin{array}{l}\text { Node } \\
\text { no:71 }\end{array}$ & $\begin{array}{l}\text { Node } \\
\text { no:51 }\end{array}$ & \\
\hline 1 & Empty & 4.04 & 3.61 & 116.46 \\
\hline 2 & Half & 4.7 & 4.22 & 136.41 \\
\hline 3 & Full & 5.36 & 4.83 & 156.36 \\
\hline
\end{tabular}

\section{CONCLUSION}

In this project, emphasis is given on the study of the in-built feature of solving seismic coefficient method in STAAD.pro V8i. This method provide the values of time period and base shear, which are very much in agreement with the values of the manually calculated results.

Parametric study is carried out by using different patterns of bracings in staging of an elevated water tank. From the table it is clear that the base shear value, reduces for alternate bracing pattern in staging. This is apparent because of the reduction of overall stiffness of the structure.

The table reveals displacement values of top node(71) and bottom node(51) of container of tank, Though it is evident that alternate cross bracing pattern gives the minimum value of displacement, but from the construction point of view and economy of overall construction, the alternate diagonal bracing pattern can be suggested.

\section{REFERENCES}

\section{Papers}

[1] Ayazhussain m. Jabar and H. S. Patel, (2012) "Seismic Behavior of RC Elevated Water Tank under Different Staging Pattern and Earthquake Characteristics". International journal of advanced engineering research and studies e-issn22498974, IJAERS/Vol. I/ Issue III/April-June, 2012/293296

[2] Durgesh C Rai, (2003) "Performance of Elevated Tanks in Mw 7.7 Bhuj Earthquake of January 26th, 2001" International journal of advanced engineering research Proc. Indian Acad. Sci. (Earth Planet. Sci.), 112, No. 3, September 2003, pp. 421-429

[3] Asari Falguni, Prof. M.G.Vanza, (2012) "Structural Control System for Elevated Water Tank" International journal of advanced engineering research and studies e-issn2249-8974, IJAERS/Vol. I/ Issue III/April-June, 2012/325-328.

[4] Hasan Jasim Mohammed,(2011) "Economical Design of Water Concrete Tanks" European journal of scientific research ISSN 1450-216x vol.49 no.4 (2011), pp. 510-520 Euro journals publishing, inc. 2011 
[5] Arun Kumar, (2006) "Ductility Analysis of R.C.C.(O.H.T) Design as Per IS:3370(Part-II)” MTech Thesis.

[6] Durgesh C. Rai and Bhumika Singh, (2004) "Seismic Design of Concrete Pedestal Supported Tanks"13th World Conference on Earthquake Engineering Vancouver, B.C, Canada August 1-6, 2004

\section{Web Sites}

[7] www.sefi.in 